Journal of the Marine Biological Association of the United Kingdom

2018, Volume 98, Issue 3, Pages 617-625

http://dx.doi.org/10.1017/S0025315416001752

http://archimer.ifremer.fr/doc/00363/47418/

(C) Marine Biological Association of the United Kingdom, 2016

\title{
Evidence of a relationship between weight and total length of marine fish in the North-eastern Atlantic Ocean: physiological, spatial and temporal variations
}

\author{
Mahé Kelig ${ }^{1,}{ }^{*}$, Bellamy Elise ${ }^{1}$, Delpech Jean-Paul ${ }^{1}$, Lazard Coline ${ }^{1}$, Salaun Michele ${ }^{1}$, Vérin Yves ${ }^{1}$, \\ Coppin Franck ${ }^{1}$, Travers-Trolet Morgane ${ }^{1}$ \\ *Corresponding author : Kelig Mahé, email address : Kelig.Mahe@ifremer
}

\begin{abstract}
:
Weight-Body Length relationships (WLR) of 45 fish species (37 Actinopterygii and eight Elasmobranchii) were investigated. A total of 31,167 individuals were caught and their biological parameters measured during the four quarters from 2013 to 2015, on five scientific surveys sampling the North-eastern Atlantic Ocean from the North Sea to the Bay of Biscay (ICES Divisions IVb, IVc, VIId, VIle, VIIg, VIIh, VIlj, VIIla and VIIlb). Among 45 tested species, all showed a significant correlation between total length $(L)$ and total weight $(W)$. The influence of sex on WLR was estimated for 39 species and presented a significant sexual dimorphism for 18 species. Condition factor $(\mathrm{K})$ of females was always higher than for males. Moreover, a spatial effect on the WLR according to five ecoregions (the Bay of Biscay, the Celtic Sea, the Western English Channel, the Eastern English Channel and the North Sea), was significant for 18 species among 38 tested species. The temporal effect was tested according to components (year and quarter/season). The seasonality effect on WLR is more frequently significant than the year especially for the Elasmobranchii species, and can be related to the spawning season. Finally, depressiform species (skates, sharks and flatfish) are characterized by positive allometric growth, whereas there is no such clear pattern regarding roundfishes growth, whatever their body shape is.
\end{abstract}

Keywords : weight-length relationship, condition factor, Bay of Biscay, Celtic Sea, English Channel, North Sea, sexual dimorphism, seasonality 
31 Biological informations, such as body length and weight, constitute necessary data for

32 assessing population structure, particularly to estimate the biomass from the length

33 frequency distribution and to convert length-at-age by weight-at-age (Froese, 2006). It

34 would be difficult to obtain the weight with a good accuracy during the sampling at

35 sea or from an underwater stereo-video system. Consequently, the characterization of

36 the Weight-Length Relationship (WLR) allows establishing readily from the one

37 known variable, the value of the other variable. Moreover, this relationship is a

38 sustainableproxy for the "fatness" and "general well-being" as the condition factor (Le

39 Cren, 1951; Tesch, 1968; Weatherley, 1972). In fish species, the weight-length

40 relationship is often defined by an exponential function under conditions of isometric

41 growth (regression follows the cube law; Ricker 1958). However, in nature, this

42 relationship depends on the environmental conditions, the physiological state of the

43 fish also has to be considered (Le Cren, 1951; Froese, 2006; Pauly, 2010; Mozsar et

44 al., 2015). Growth coefficient (b) varies between 2.5 and 4 (Hile, 1936; Martin, 1949;

45 Pauly \& Gayanilo, 1997; Froese, 1998; 2006. In this study, the influence of factors

46 such as sampling year and quarter, geographical area and sex were evaluated through

47 the body length-weight relationships (WLR) which were estimated for 45 species,

48 sampled during five surveys operating from the North Sea to the Bay of Biscay and

49 covering all length range from juveniles to adults. 
51 Sampling was realized on the research vessels "Thalassa" and "Gwen-Drez" each year 52 from 2013 to 2015, duringfive surveys (Figure 1):

Elasmobranchii (n=2084) represented by 8 species. (Table 1; Anonyme, 2016).

70 Preliminary to the characterization of the W-L relationship, all pairs of data for each

71 species were plotted in order to identify and delete obvious outliers. In order to 
72 estimate the parameters of the allometric W-L relationship (Eq. 1), its base-10

73 logarithm (Eq. 2) was fitted for each species to data using a least squared linear model:

$$
W=a L^{b} \quad \text { (Eq. 1) }
$$

$$
\log W=\log a+b \log L \quad \text { (Eq. 2) }
$$

76 Where ' $a$ ' is the intercept or initial growth coefficient and ' $b$ ' is the slope i.e. the

77 growth coefficient (Le Cren, 1951; Ricker, 1975; Froese, 2006).

78 To investigate variations of the relationship between body length and weight for each

79 species a completed Generalized Linear Model was performed according to the 80 explanatory variables: divisions VIIIa \& VIIIb),

Sex (S): Female and Male,

For each species, when data set resulting of explanatory variables was lower than ten,

89 these data were deleted. The individual weight of each species was modeled such as

90 depending on body length as continuous effect and geographical area, sex and

91 sampling year and quarter as factors (Eq. 3):

$92 \log \mathrm{W} \sim \log L+A+S+Y+Q+\log L \times A+\log L \times S+\log L \times Y+\log L \times Q$ (Eq. 3) 
With the separate influence of factors A $(\log L x A), \mathrm{S}(\log L x S), \mathrm{Y}(\log L x Y)$ and Q

$(\log L \times Q)$ on the relationship between body length and weight. For each species, the normality of data set was tested by a Quantile-Quantile Plot of the residuals (Zuur et al., 2007).

To characterize the difference in the W-L relationship for each species of fish, the condition factor, K, has been employed (Le Cren, 1951, Eq. 4):

$$
\mathrm{K}=1000 . \mathrm{W} / \mathrm{L}^{3} \text { (Eq. 4) }
$$

100 Fish with a high value of K are heavy for their length, while fish with a low value are 101 light for their length.

102 All statistical analyses were carried out using the 'CAR' package (Fox \& Weisberg, 103 2011) in the statistical environment $R$ ( $R$ Core Team, 2016).

RESULTS

105 Information relative to each species are presented in Table 1 with the number of measured specimens, the type of body length and the minimum, maximum and mean \pm standard deviation of length and weight. Measured length and weight ranged respectively from $3 \mathrm{~cm}$ (Chelidonichthys lucerna) to $220 \mathrm{~cm}$ (Conger conger) and 109 from $1 \mathrm{~g}$ to $45000 \mathrm{~g}$ (Conger conger) (Table 1). The samples were distributed by sex, 110 sampling year, sampling quarter and by geographical area (Supplementary Table 1).

111 Among the 45 tested species, all showed a significant correlation $(\mathrm{P}<0.05)$ between 112 body length and weight. The four explanatory variables presented significant effect on 113 the WLR (Table 2), but only for whiting (Merlangius merlangus) and striped red 114 mullet (Mullus surmuletus), all the four has been effectively significant in the same 115 time. The influence of sex factor was estimated on the 39 species, for which 
macroscopic observation allows sex identification. Slopes of W-L relationship were significantly different between males and females on only 18 species $(46.1 \%)$ of which 14 Actinopterygii (Pleuronectes platessa, Limanda limanda, Microstomus kitt, Dicentrarchus labrax, Merluccius merluccius, Merlangius merlangus, Mullus surmuletus, Platichthys flesus, Solea solea, Trachinus draco, Scophthalmus maximus, Phycis blennoides, Chelidonichthys cuculus, Trisopterus esmarkii) and 4 Elasmobranchii (Mustelus asterias Scyliorhinus canicula, Raja clavata, Raja montagui) (Table 1). The effect of the sex factor is more often observed in Elasmobranchii (50\%) than in Actinopterygii (35.1\%). Nevertheless, in Actinopterygii, this result fluctuated according to the fish shape (66.6\% of flatfishes versus $21.9 \%$ of roundfishes). The geographical factor which was divided in 5 samplings ecoregions from the Bay of Biscay to the North Sea, was significant on W-L relationship of only 18 species among 38 tested species (species occurring in sufficient number in both areas) (47.4\%). These species were composed of 17 Actinopterygii (Hyperoplus immaculatus, Limanda limanda, Merlangius merlangus, Chelidonichthys cuculus, Lophius piscatorius, Sardina pilchardus, Gadus morhua, Lophius budegassa, Microstomus kitt, Phycis blennoides, Merluccius merluccius, Melanogrammus aeglefinus, Dicentrarchus labrax, Solea solea, Mullus surmuletus, Pollachius pollachius, Pleuronectes platessa) and only 1 Elasmobranchii (Raja undulata) (Table 2). Contrary to the sexual dimorphism, the spatial effect on the body length-weight relationships was measured essentially for the Actinopterygii. The temporal effect on the WLR must be divided at two observation scales with the variations inter-years and intra-year (seasonality effect represented by the quarters). Among the 29 tested species with both temporal effects, only five (17.2\%, Gadus morhua, Merlangius merlangus, Lophius piscatorius, Mullus surmuletus, Mustelus asterias) presented significant variations inter-years and intra-year. Separately, the year effect and the seasonality 
142 effect were significant at the level of $32.4 \%$ and $35.3 \%$ respectively. The seasonality 143 effect $(42.8 \%)$ was more significant than between years $(11.1 \%)$ in Elasmobanchii 144 (Table 2). The parameters of the body length-weight relationships are given in 145 Supplementary Table 2. The initial growth coefficient 'a' varied from $4.210^{-4} \pm 1.010^{-}$ 1465 in Conger conger to $6.610^{-2} \pm 4.810^{-2}$ in Scophthalmus maximus, while the growth 147 coefficient ' $b$ ' ranged from $2.7 \pm 1.210^{-2}$ in Hyperoplus immaculatus to $3.5 \pm 8.210^{-3}$ in 148 Conger conger. The coefficients of the WLR are significantly correlated (Figure 2). 149 Among the 45 tested species, the value of $b$ was under 3 for 14 species $(31.1 \%)$ with 15012 roundfishes and 2 flatfishes (Supplementary Table 2). All elasmobranchii species 151 presented positive allometric growth (coefficient b higher than 3) (Supplementary 152 Table 2; Figure 2). To compare the fatness of each fish species according to 153 geographical area, sex and sampling year and quarter, the condition factor $(\mathrm{K})$ was 154 estimated (Table 3). In the event of significant sexual dimorphism, all condition 155 factors (K) of females were higher than those of males (Table 3). For the others tested 156 factors, the highest values of $\mathrm{K}$ were distributed between all sampled years, areas and 157 quarters (Table 3).

\section{DISCUSSION}

159 This study with large sample data $(n=31167)$ showed the allometric W-L relationship 160 and the factors influencing this type of data. According to Hile (1936), Martin (1949), 161 Pauly \& Gayanilo (1997) and Froese $(1998,2006)$, 'b' values may range from 2.5 to 1623.5 for fish, which is the case for the values estimated in our study. Moreover, the study showed that the coefficients of the WLR were significantly correlated. The 164 growth coefficient (b) reflected firstly the shape and the fatness of the fish species. 165 Consequently, the elasmobranchii (sharks and skates) and the flatfishes presented an 166 only one body shape, as know as depressiform, and consequently the weight growth 
167 higher than the length growth (b>3; Figure 2). This result corroborated the results 168 obtained for the elasmobranchii (Pallaoro et al., 2005; Yeldan and Avsar, 2007; Yığın 169 and Ismen 2009) and for the soleidae (Torres et al., 2012). Among 28 roundfishes 170 species, the $b$ values were within the range of 2.5-3.5 and there was no observed trend 171 in body shape due to its large range of shapes as fusiform (i.e. Gadus morhua), arrow172 like (i.e. Hyperoplus immaculatus), ribbon-like (Conger conger) or laterally flattened 173 (i.e. Trachurus trachurus). The difference of shapes could be characterised by the

174 'form factor' equation $\left(a_{3,0}=10^{\log a-S(b-3)}\right)$ of the log a-b relationship (Froese, 2006; 175 Verreycken et al., 2011).

176 For all 45 species, the body length-weight relationship was significant. Our analyses 177 confirmed those observed in the North-Eastern Atlantic ocean (Dorel, 1986; Coull et 178 al., 1989; Silva et al., 2013; Wilhelms, 2013), in Greek waters (Petrakis \& Stergiou, 179 1995), in Persian Gulf (Naderi et al., 2013), in the Aegean Sea (Moutopoulos \& 180 Stergiou, 2002). Consequently, it is possible for these marine species to use W-L 181 relationship to estimate weight from length or vice versa. For each species, significant 182 difference nevertheless could be observed according to sex, to the sampled year, 183 seasonality and geographical area. The first tested factor is the sex. The sexual 184 dimorphism influenced significantly the W-L relationship of few species as observed 185 in the Azores islands (Morato et al., 2001). The difference observed between males 186 and females for striped red mullet (Mullus surmuletus) corroborated the previous study 187 on this species during 2004 in the Eastern English Channel (Mahé et al., 2013). The 188 results of sexual dimorphism effect on the WLR were similar in the Eastern Adriatic 189 Sea, except for Mustelus asterias, but the low number in the Mediterranean Sea for 190 one species with large length range could be one explanation (Pallaoro et al., 2005). 191 There was sexual dimorphism according to the value of $\mathrm{K}$, indicated that at the same 
192 length, females are heavier than the males. This trend was observed in the 193 actinopterygii and elasmobranchii. This study was realized by five surveys covering 194 all ecoregions, from the Bay of Biscay to the North Sea. Consequently, significant 195 differences in their W-L relationship were observed for many widely distributed 196 species across their distribution area. These difference were a result of many 197 morphotypes within a species or a family. For striped red mullet (Mullus surmuletus), 198 there were 2 morphotypes according to the head shape between South and North 199 populations (bay of Biscay/ Eastern English Channel (Mahé et al., 2014)), which 200 could explained the observed difference of condition factors. The head morphological 201 variation, for one species between two geographical areas or habitats, is influenced by 202 feeding behavior (Hyndes et al., 1997; Janhunen et al., 2009). Within a family, values 203 or the trend of condition factors between two similar species could be opposite. This 204 has been observed between Lophius budegassa and Lophius piscastorius and between 205 Scophthalmus maximus and Scophthalmus rhombus during the same sampling years 206 and quarters. Seasonal or annual differences in W-L relationships and therefore in 207 condition factor, may be generally related to reproduction (gonad development and 208 spawning period) or feeding activities (food availability and feeding rate) (Bagenal \& 209 Tesch, 1978; Weatherley \& Gill, 1987; Wootton, 1990) but also attributed to 210 differences in sampling especially length ranges too. Throughout a year, significant 211 difference of the condition factor according to the spawning period for each species 212 (Supplementary Table 3), showed than the specimens were the heaviest just before and 213 during the spawning period. This seasonal oscillation of the WLR and the condition 214 factor could be explained by the environmental factors as the temperature but also by 215 the availability of food and the physiological state of the fish (i.e. degree of gonad 216 development) (Le Cren 1951; Froese, 2006; Pauly, 2010; Mozsar et al., 2015). 
218 We would like to express our gratitude to all people involved in the collection of 219 samples required in this study. Thanks are expressed to all scientists and the crew of 220 the RV «Thalassa » and the RV « Gwen-Drez » during the IBTS, CAMANOC, 221 CGFS, EVHOE and LANGOLF surveys for their help with sample collection. We 222 acknowledge the help of Mark Etherton for improvement of the language. We are 223 grateful for the comments provided by the reviewers.

\section{FINANCIAL SUPPORT}

226 This study was supported by the Data Collection Framework (DCF; EC Reg. 227 199/2008, 665/2008; Decisions 2008/949/EC and 2010/93/EU) and the French FFP 228 project DYSTRETE.

REFERENCES

231 Anonyme (2016) World Register of Marine Species. Available at 232 http://www.marinespecies.org (accessed 2 February 2016).

233 Bagenal T.B. and Tesch F.W. (1978) Age and growth. In Begenal T. (ed) Methods 234 for assessment of fish production in fresh waters, Oxford, Blackwell Science 235 Publications, pp 101-136.

236 Coull K.A., Jermyn A.S., Newton A.W., Henderson G.I. and Hall W.B. (1989) 237 Length/weight relationships for 88 species of fish encountered in the North Atlantic. 238 Scottish Fisheries Research Report, no. 43, 80 pp.

239 Dorel D. (1986) Poissons de l'Atlantique Nord-Est : Relations Taille-Poids. IFREMER 240 Publications, Nantes, no 1, 183 pp. 
241 Fox J. and Weisberg S. (2011) An $\{R\}$ Companion to Applied Regression. 2nd 242 edition. Thousand Oaks CA.

243 Froese R. (1998) Length-weight relationships for 18 less-studied fish species. Journal 244 of Applied Ichthyology 14, 117-118.

245 Froese R. (2006) Cube law, condition factor and weight-length relationships: history, 246 meta-analysis and recommendations. Journal of Applied Ichthyology 22, 241-253.

247 Hile R. (1936) Age and growth of Cisco, Leuhthys artedi (Le Suer) in the lake of 248 north-eastern high lands. Bulletin of the United States Bureau of Fisheries 48, 211249317

250 Hyndes G.A., Platell M.E. and Potter I.C. (1997) Relationships between diet and 251 body size, mouth morphology, habitat and movement of six sillaginid species in 252 coastal waters: implications for resource partitioning. Marine Biology 128, 585-598.

253 Janhunen M., Peuhkuri N. and Piironen J. (2009) Morphological variability among 254 three geographically distinct Arctic charr (Salvelinus alpinus L.) populations reared in 255 a common hatchery environment. Ecology of Freshwater Fish 18, 106-116.

256 Le Cren E.D. (1951) The length-weight relationship and seasonal cycle in gonad 257 weight and condition in the perch (Perca fluviatilis). Journal of Animal Ecology 20, $258 \quad 201-219$.

259 Mahe K., Coppin F., Vaz S. and Carpentier A. (2013) Striped red mullet (Mullus 260 surmuletus, Linnaeus, 1758) in the eastern English Channel and southern North Sea: 261 growth and reproductive biology. Journal of Applied Ichthyology 29(5), 1067-1072.

262 Mahe K., Villanueva C.-M., Vaz S., Coppin F., Koubbi P. and Carpentier A. 263 (2014) Morphological variability of the shape of striped red mullet Mullus surmuletus 
264 in relation to stock discrimination between the Bay of Biscay and the eastern English

265 Channel. Journal of Fish Biology 84(4), 1063-1073.

266 Martin W.R. (1949) The mechanics of environmental control of body form in fishes.

267 University of Toronto biological studies, no 56, $91 \mathrm{pp}$.

268 Morato T., Afonso P., Lourinho P., Barreiros J.P., Santos R.S. and Nash R.D.M.

269 (2001) Length-weight relationships for 21 coastal fish species of the Azores, north270 eastern Atlantic. Fisheries Research 50(3),,297-302.

271 Moutopoulos D.K. and Stergiou K.I. (2002) Length-weight and length-length

272 relationships of fish species from the Aegean Sea (Greece). Journal of Applied 273 Ichthyology 18, 200-203.

274 Mozsar A., Boros G., Sály P., Antal L. and Nagy S.A. (2015) Relationship between 275 Fulton's condition factor and proximate body composition in three freshwater fish 276 species. Journal of Applied Ichthyology 31, 315-320.

277 Naderi M., Zare P. and Azvar E. (2013) Length-weight relationships for five 278 stingray species from the Persian Gulf. Journal of Applied Ichthyology 29, 1177-1178.

279 Pallaoro A., Jardas I. and Santic M. (2005) Weight-length relationships for 11 280 chondrichthyan species in the eastern Adriatic Sea. Cybium 29, 93-96.

281 Pauly D. (2010) Gasping Fish and Panting Squids: Oxygen, Temperature and the 282 Growth of Water-Breathing Animals. Excellence in Ecology, International Ecology 283 Institute, no 22, $216 \mathrm{pp}$.

Pauly D. and Gayanilo Jr.F.C. (1997) A Bee: An alternative approach to estimating the parameters of a length-weight relationship from length frequency samples and their bulk weights, NAGA ICLARM, Manila, Philippines.

287 Petrakis G. and Stergiou K.I. (1995) Weight-length relationship for 33 fish species 288 in Greek waters. Fisheries Research 21, 465-469. 
289 R Core Team (2016) R: A language and environment for statistical computing. $R$ 290 Foundation for Statistical Computing, Vienna, Austria.

291 Ricker W.E. (1975) Computation and interpretation of the biological statistics of fish 292 populations. Bulletin Fisheries Research Board of Canada 191, 1-382.

293 Silva J.F., Ellis J.R. and Ayers R.A. (2013) Length-weight relationships of marine 294 fish collected from around the British Isles. Science Series Technical report, 295 Lowestoft, Cefas publications, no 150, 109 pp.

296 Tesch F.W. (1968) Age and growth. In Ricker W.E. (ed.) Methods for assessment of 297 fish production in fresh waters. Oxford, Blackwell Scientific Publications, pp 93-123.

298 Torres M.A., Ramos F. and Sobrino I. (2012) Length-weight relationships of 76 fish 299 species from the Gulf of Cadiz (SW Spain). Fisheries Research 127-128, 171-175.

300 Verreycken H., Van Thuyne G. and Belpaire C. (2011) Length-weight 301 relationships of 40 freshwater fish species from two decades of monitoring in Flanders 302 (Belgium). Journal of Applied Ichthyology 27, 1416-1421.

303 Weatherley A.H. and Gill H.S. (1987) The biology of fish growth. London: 304 Academic Press.

305 Wilhelms I. (2013) Atlas of length-weight relationships of 93 fish and crustacean 306 species from the North Sea and the North-East Atlantic, Thünen Working Paper, no. $307 \quad 12,552 \mathrm{pp}$

308 Wootton R.J. (1990) Ecology of teleost fish. London: Chapman \& Hall.

309 Yeldan H. and Avsar D. (2007) Length-weight relationship for five elasmobranch 310 species from the Cilician Basin shelf waters (Northeastern Mediterranean). Journal of 311 Applied Ichthyology 23, 713-714.

312 Yığın C.C. and Ismen A. (2009) Length-weight relationships for seven rays from 313 Saros Bay (North Aegean Sea). Journal of Applied Ichthyology 25, 106-108. 
314 Zuur A.F., Ieno E.N. and Smith G.M. (2007) Analysing ecological data. New York:

315 Springer Science.

316

317

318

319

320

321

322

323

324

325

326

327

328

329

330

331

332

333

334 
Figure 1. Location of trawling stations from the bay of Biscay to the North Sea (ICES Division IVa, IVb, VIId, VIIe, VIIf, VIIg, VIIh, VIIIa \& VIIIb) where the 31167 individuals used in this study have been sampled.

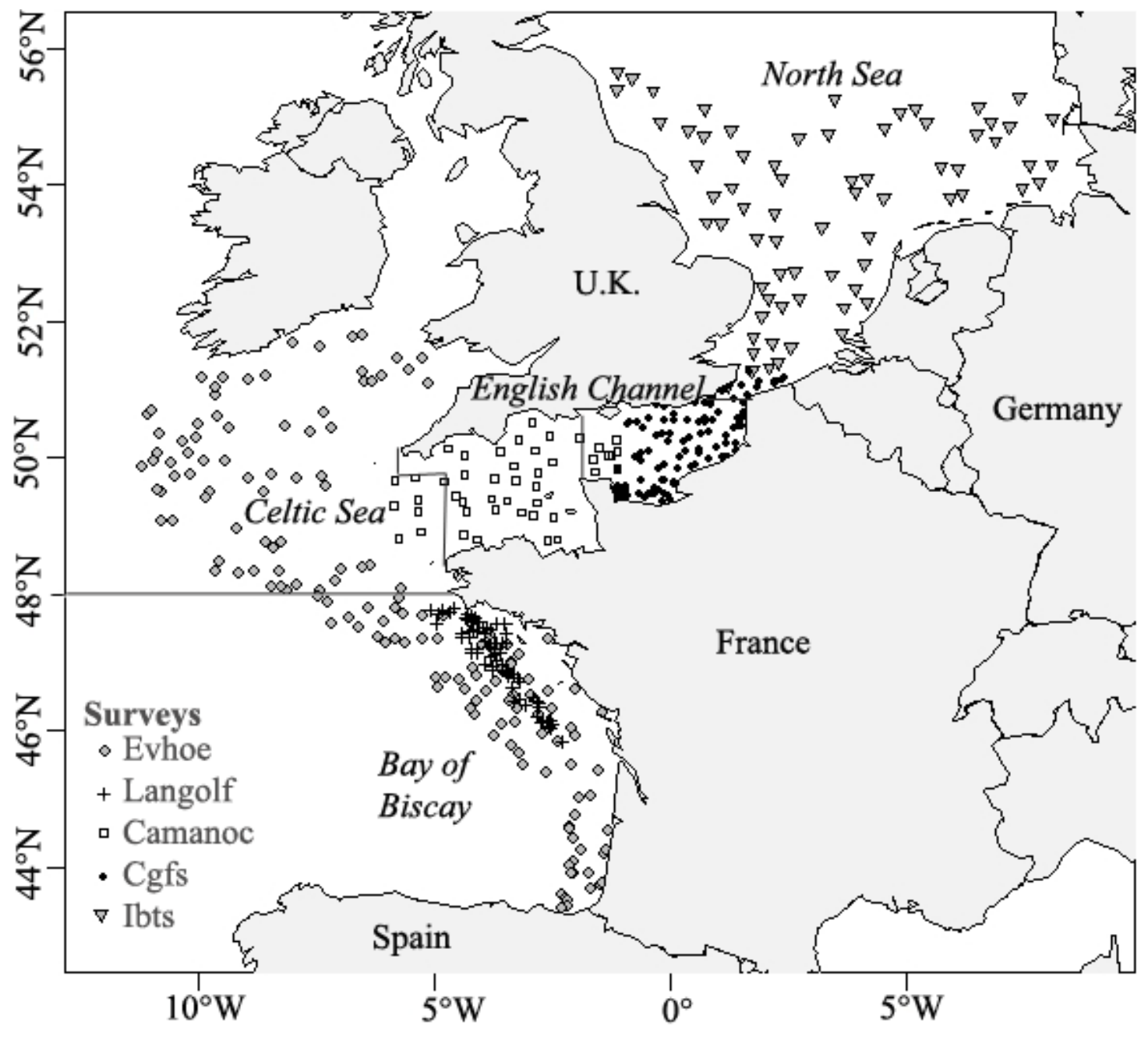


346 Figure 2. Scatter plot of mean $\log$ a (TL) over mean $b$ for 45 fish species by 347 distinguishing the actinopterygii (roundfishes and flatfishes) and the elasmobranchii 348 (sharks and skates) with body shape information (see legend). The regression line was 349 realized from 45 fish species.

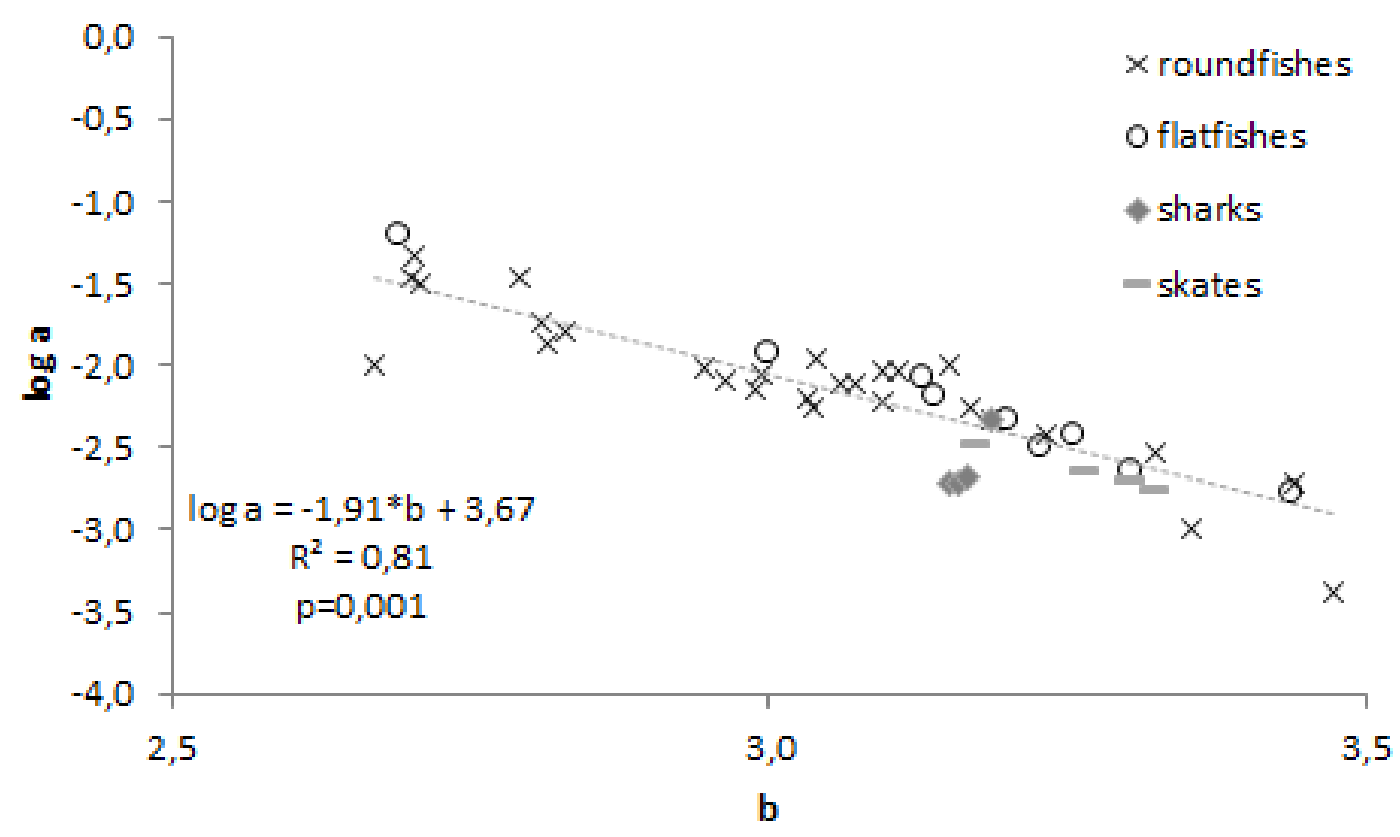

350

351

352

353

354

355 
361 length range $(\mathrm{cm})$, mean length \pm standard deviation $(\mathrm{cm})$, weight range $(\mathrm{g})$ and mean

362 weight \pm standard deviation $(\mathrm{g})$. Within each class, species are listed in alphabetical order of their family.

\begin{tabular}{|c|c|c|c|c|c|c|c|}
\hline Order & Family & Species & $\mathbf{n}$ & $\begin{array}{l}\text { Mean length } \pm \\
\text { SD }\end{array}$ & $\begin{array}{c}\text { Length } \\
\text { range } \\
\text { (cm) }\end{array}$ & Mean weight \pm SD & $\begin{array}{c}\text { Weight range } \\
\text { (g) }\end{array}$ \\
\hline \multicolumn{8}{|c|}{ Actinopterygii } \\
\hline \multirow{28}{*}{ 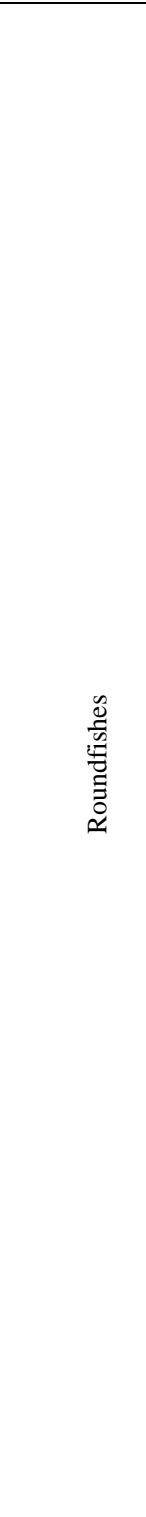 } & Ammodytidae & Hyperoplus immaculatus & 139 & $23,28 \pm 3,30$ & $13 / 36$ & $34,2 \pm 12,9$ & $6 / 90$ \\
\hline & Carangidae & Trachurus trachurus & 244 & $19,11 \pm 8,13$ & $7 / 39$ & $99,7 \pm 101,3$ & $4 / 540$ \\
\hline & \multirow{3}{*}{ Clupeidae } & Clupea harengus & 1342 & $20,93 \pm 5,21$ & $9 / 34$ & $70,2 \pm 51,0$ & $5 / 292$ \\
\hline & & Sardina pilchardus & 111 & $18,30 \pm 3,31$ & $9 / 26$ & $53,3 \pm 29,7$ & $7 / 138$ \\
\hline & & Sprattus sprattus & 627 & $10,81 \pm 2,16$ & $5 / 15$ & $12,4 \pm 55,8$ & $1 / 1400$ \\
\hline & Congridae & Conger conger & 94 & $90,50 \pm 38,80$ & $32 / 220$ & $3279,3 \pm 6185,3$ & $46 / 45000$ \\
\hline & Engraulidae & Engraulis encrasicolus & 289 & $13,62 \pm 2,26$ & $8 / 20$ & $17,6 \pm 10,9$ & $1 / 66$ \\
\hline & \multirow{8}{*}{ Gadidae } & Gadus morhua & 1452 & $45,80 \pm 18,43$ & $11 / 126$ & $1567,4 \pm 2172,2$ & $15 / 24020$ \\
\hline & & $\begin{array}{c}\text { Melanogrammus } \\
\text { aeglefinus }\end{array}$ & 1476 & $36,50 \pm 12,66$ & $12 / 77$ & $698,0 \pm 753,7$ & $17 / 4900$ \\
\hline & & Merlangius merlangus & 6820 & $27,28 \pm 8,13$ & $8 / 62$ & $220,0 \pm 211,6$ & $1 / 2348$ \\
\hline & & Micromesistius poutassou & 52 & $15,77 \pm 2,94$ & $13 / 27$ & $30,2 \pm 25,5$ & $15 / 149$ \\
\hline & & Pollachius pollachius & 50 & $54,36 \pm 14,16$ & $15 / 82$ & $1815,2 \pm 1156,5$ & $38 / 3894$ \\
\hline & & Trisopterus esmarkii & 121 & $14,02 \pm 3,60$ & $9 / 25$ & $3756,1 \pm 7301,3$ & $5 / 40000$ \\
\hline & & Trisopterus luscus & 506 & $24,79 \pm 6,23$ & $9 / 41$ & $230,1 \pm 156,4$ & $8 / 900$ \\
\hline & & Trisopterus minutus & 164 & $14,73 \pm 3,25$ & $7 / 20$ & $38,4 \pm 19,8$ & $4 / 88$ \\
\hline & \multirow{2}{*}{ Lophiidae } & Lophius budegassa & 489 & $29,94 \pm 14,95$ & $5 / 82$ & $726,4 \pm 1054,8$ & $2 / 7800$ \\
\hline & & Lophius piscatorius & 375 & $41,61 \pm 22,53$ & $9 / 115$ & $2007,9 \pm 2878,3$ & $10 / 19720$ \\
\hline & Merlucciidae & Merluccius merluccius & 2038 & $39,37 \pm 19,79$ & $6 / 121$ & $799,4 \pm 1283,4$ & $1 / 11100$ \\
\hline & Moronidae & Dicentrarchus labrax & 417 & $46,11 \pm 11,35$ & $16 / 83$ & $1221,8 \pm 969,1$ & $43 / 7140$ \\
\hline & Mullidae & Mullus surmuletus & 904 & $19,34 \pm 5,99$ & $8 / 39$ & $122,9 \pm 111,8$ & $6 / 880$ \\
\hline & Phycidae & Phycis blennoides & 579 & $31,43 \pm 10,25$ & $13 / 60$ & $323,7 \pm 308,5$ & $14 / 1870$ \\
\hline & Scombridae & Scomber scombrus & 43 & $31,33 \pm 4,77$ & $19 / 43$ & $301,0 \pm 174,9$ & $56 / 830$ \\
\hline & Sparidae & Spondyliosoma cantharus & 209 & $21,62 \pm 10,06$ & $5 / 48$ & $294,4 \pm 353,6$ & $4 / 2190$ \\
\hline & Trachinidae & Trachinus draco & 62 & $33,66 \pm 6,74$ & $12 / 47$ & $291,8 \pm 145,6$ & $10 / 682$ \\
\hline & \multirow{3}{*}{ Triglidae } & Eutrigla gurnardus & 266 & $24,04 \pm 6,47$ & $8 / 38$ & $147,8 \pm 109,5$ & $5 / 480$ \\
\hline & & Chelidonichthys cuculus & 1343 & $25,5 \pm 5,9$ & $7 / 42$ & $186,1 \pm 124,5$ & $10 / 796$ \\
\hline & & Chelidonichthys lucerna & 176 & $31,18 \pm 8,30$ & $3 / 64$ & $380,5 \pm 422,2$ & $1 / 3080$ \\
\hline & Zeidae & Zeusfaber & 251 & $32,55 \pm 13,24$ & $4 / 67$ & $773,3 \pm 727,3$ & $3 / 4900$ \\
\hline \multirow{4}{*}{ 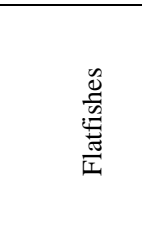 } & \multirow{3}{*}{ Scophthalmidae } & $\begin{array}{c}\text { Lepidorhombus } \\
\text { whiffiagonis }\end{array}$ & 977 & $29,85 \pm 10,11$ & $7 / 58$ & $271,9 \pm 277,6$ & $5 / 1450$ \\
\hline & & Scophthalmus maximus & 74 & $39,92 \pm 10,99$ & $17 / 63$ & $1613,1 \pm 1332,0$ & $92 / 6070$ \\
\hline & & Scophthalmus rhombus & 61 & $36,07 \pm 7,23$ & $21 / 57$ & $741,8 \pm 523,2$ & $175 / 2750$ \\
\hline & Soleidae & Solea solea & 945 & $26,14 \pm 7,35$ & 9/49 & $206,5 \pm 184,6$ & $4 / 1300$ \\
\hline
\end{tabular}




\begin{tabular}{|c|c|c|c|c|c|c|c|}
\hline & \multirow{5}{*}{ Pleuronectidae } & $\begin{array}{c}\text { Glyptocephalus } \\
\text { cynoglossus }\end{array}$ & 117 & $32,42 \pm 5,62$ & $18 / 43$ & $257,1 \pm 135,1$ & $30 / 592$ \\
\hline & & Limanda limanda & 985 & $20,85 \pm 5,10$ & $5 / 37$ & $114,4 \pm 85,2$ & $2 / 620$ \\
\hline & & Microstomus kitt & 503 & $25,98 \pm 5,27$ & $10 / 45$ & $238,9 \pm 152,3$ & $10 / 1175$ \\
\hline & & Platichthys flesus & 98 & $28,15 \pm 5,15$ & $15 / 39$ & $280,2 \pm 175,8$ & $35 / 960$ \\
\hline & & Pleuronectes platessa & 4684 & $28,08 \pm 7,09$ & $10 / 57$ & $257,0 \pm 209,1$ & $5 / 1945$ \\
\hline Elasmobranchii & & & & & & & \\
\hline & Arhynchobatidae & Raja brachyurops & 45 & $60,98 \pm 20,93$ & $30 / 103$ & $2075,6 \pm 2235,1$ & $142 / 10650$ \\
\hline & & Raja clavata & 608 & $62,25 \pm 17,69$ & $3 / 112$ & $2082,7 \pm 1597,0$ & $50 / 7340$ \\
\hline & Rajidae & Raja montagui & 82 & $47,94 \pm 15,23$ & $12 / 74$ & $943,2 \pm 733,3$ & $5 / 2700$ \\
\hline & & Raja undulata & 144 & $68,08 \pm 20,51$ & $27 / 100$ & $2892,9 \pm 2206,7$ & $200 / 7860$ \\
\hline & & Scyliorhinus canicula & 176 & $50,93 \pm 11,12$ & $10 / 67$ & $504,0 \pm 377,1$ & $18 / 3900$ \\
\hline & & Scyliorhinus stellaris & 250 & $70,76 \pm 23,84$ & $17 / 113$ & $2095,8 \pm 1746,8$ & $48 / 6660$ \\
\hline & & Galeorhinus galeus & 87 & $93,14 \pm 20,32$ & $48 / 150$ & $4116,8 \pm 3163,7$ & $514 / 17040$ \\
\hline & & Mustelus asterias & 692 & $80,78 \pm 16,68$ & $33 / 127$ & $2328,8 \pm 1552,5$ & $116 / 8660$ \\
\hline
\end{tabular}


Table 2. $\mathrm{P}$ value for the relationship between body length and weight (W-L) and for the influence of sex, geographical area, sampling year and quarter on the W-L relationship ( $\mathrm{p}<0.05$ in grey square) of the 45 fish species caught from the Bay of

381 Biscay to the North Sea during 2013, 2014 and 2015 years. If the factor was not tested because there was only one modality, there was no value in the case (-).

\begin{tabular}{|c|c|c|c|c|c|c|c|}
\hline Order & Family & Species & W-L & Area & Year & Quarter & Sex \\
\hline \multicolumn{8}{|c|}{ Actinopterygii } \\
\hline \multirow{28}{*}{ 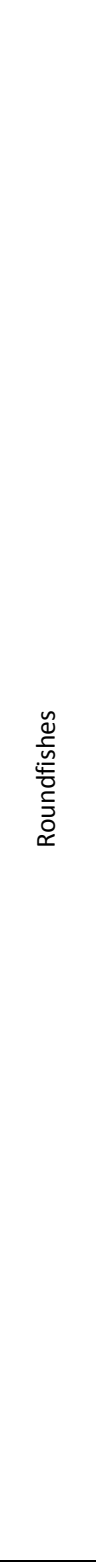 } & Ammodytidae & Hyperoplus immaculatus & $<0,001$ & $<0,001$ & - & 0,646 & - \\
\hline & Carangidae & Trachurus trachurus & $<0,001$ & 0,602 & - & 0,186 & - \\
\hline & \multirow{3}{*}{ Clupeidae } & Clupea harengus & $<0,001$ & 0,139 & $<0,001$ & - & 0,918 \\
\hline & & Sardina pilchardus & $<0,001$ & $<0,001$ & 0,026 & - & 0,621 \\
\hline & & Sprattus sprattus & $<0,001$ & 0,562 & 0,174 & - & 0,099 \\
\hline & Congridae & Conger conger & $<0,001$ & 0,092 & 0,097 & 0,745 & - \\
\hline & Engraulidae & Engraulis encrasicolus & $<0,001$ & 0,322 & 0,725 & 0,002 & 0,778 \\
\hline & \multirow{8}{*}{ Gadidae } & Gadus morhua & $<0,001$ & $<0,001$ & 0,092 & $<0,001$ & 0,729 \\
\hline & & $\begin{array}{c}\text { Melanogrammus } \\
\text { aeglefinus }\end{array}$ & $<0,001$ & 0,004 & 0,191 & $<0,001$ & 0,585 \\
\hline & & Merlangius merlangus & $<0,001$ & $<0,001$ & 0,018 & $<0,001$ & 0,008 \\
\hline & & $\begin{array}{c}\text { Micromesistius } \\
\text { poutassou }\end{array}$ & $<0,001$ & - & - & - & - \\
\hline & & Pollachius pollachius & $<0,001$ & 0,045 & 0,120 & 0,443 & 0,413 \\
\hline & & Trisopterus esmarkii & $<0,001$ & - & $<0,001$ & - & 0,049 \\
\hline & & Trisopterus luscus & $<0,001$ & 0,745 & $<0,001$ & 0,934 & 0,225 \\
\hline & & Trisopterus minutus & $<0,001$ & 0,616 & - & 0,053 & - \\
\hline & \multirow{2}{*}{ Lophiidae } & Lophius budegassa & $<0,001$ & $<0,001$ & 0,289 & 0,438 & 0,764 \\
\hline & & Lophius piscatorius & $<0,001$ & $<0,001$ & $<0,001$ & 0,039 & 0,562 \\
\hline & Merlucciidae & Merluccius merluccius & $<0,001$ & 0,002 & 0,392 & 0,003 & 0,008 \\
\hline & Moronidae & Dicentrarchus labrax & $<0,001$ & 0,005 & 0,403 & 0,162 & 0,002 \\
\hline & Mullidae & Mullus surmuletus & $<0,001$ & 0,020 & $<0,001$ & $<0,001$ & 0,047 \\
\hline & Phycidae & Phycis blennoides & $<0,001$ & 0,001 & 0,731 & - & 0,040 \\
\hline & Scombridae & Scomber scombrus & $<0,001$ & - & - & - & - \\
\hline & Sparidae & $\begin{array}{c}\text { Spondyliosoma } \\
\text { cantharus }\end{array}$ & $<0,001$ & 0,123 & - & 0,586 & 0,225 \\
\hline & Trachinidae & Trachinus draco & $<0,001$ & - & - & - & 0,016 \\
\hline & \multirow{3}{*}{ Triglidae } & Eutrigla gurnardus & $<0,001$ & 0,600 & 0,611 & 0,629 & 0,233 \\
\hline & & Chelidonichthys cuculus & $<0,001$ & $<0,001$ & 0,001 & 0,583 & 0,047 \\
\hline & & Chelidonichthys Iucerna & $<0,001$ & 0,544 & 0,327 & 0,850 & 0,498 \\
\hline & Zeidae & Zeus faber & $<0,001$ & 0,944 & 0,565 & $<0,001$ & 0,585 \\
\hline \multirow{4}{*}{ 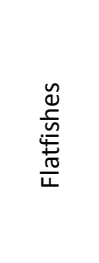 } & \multirow{3}{*}{ Scophthalmidae } & $\begin{array}{c}\text { Lepidorhombus } \\
\text { whiffiagonis }\end{array}$ & $<0,001$ & 0,971 & $<0,001$ & 0,909 & 0,867 \\
\hline & & Scophthalmus maximus & $<0,001$ & 0,808 & 0,322 & 0,446 & 0,016 \\
\hline & & Scophthalmus rhombus & $<0,001$ & 0,280 & 0,137 & 0,279 & 0,288 \\
\hline & Soleidae & Solea solea & $<0,001$ & 0,007 & 0,274 & 0,119 & 0,016 \\
\hline
\end{tabular}




\begin{tabular}{|c|c|c|c|c|c|c|c|}
\hline & \multirow{5}{*}{ Pleuronectidae } & $\begin{array}{c}\text { Glyptocephalus } \\
\text { cynoglossus }\end{array}$ & $<0,001$ & - & 0,650 & - & 0,542 \\
\hline & & Limanda limanda & $<0,001$ & $<0,001$ & 0,041 & 0,188 & $<0,001$ \\
\hline & & Microstomus kitt & $<0,001$ & 0,001 & $<0,001$ & 0,222 & 0,001 \\
\hline & & Platichthys flesus & $<0,001$ & 0,882 & - & - & 0,009 \\
\hline & & Pleuronectes platessa & $<0,001$ & 0,045 & 0,127 & $<0,001$ & $<0,001$ \\
\hline \multicolumn{8}{|c|}{ Elasmobranchii } \\
\hline & Arhynchobatidae & Raja brachyurops & $<0,001$ & - & 0,077 & - & 0,404 \\
\hline & \multirow{3}{*}{ Rajidae } & Raja clavata & $<0,001$ & 0,366 & 0,078 & 0,584 & 0,005 \\
\hline & & Raja montagui & $<0,001$ & 0,334 & 0,667 & 0,171 & 0,009 \\
\hline & & Raja undulata & $<0,001$ & 0,019 & 0,181 & 0,020 & 0,428 \\
\hline & \multirow{2}{*}{ Scyliorhinidae } & Scyliorhinus canicula & $<0,001$ & 0,180 & 0,139 & $<0,001$ & $<0,001$ \\
\hline & & Scyliorhinus stellaris & $<0,001$ & 0,564 & 0,669 & 0,592 & 0,237 \\
\hline & \multirow{2}{*}{ Trakidae } & Galeorhinus galeus & $<0,001$ & - & 0,406 & 0,686 & 0,382 \\
\hline & & Mustelus asterias & $<0,001$ & 0,643 & 0,000 & 0,011 & 0,000 \\
\hline
\end{tabular}


397 Table 3. Mean value of condition factor (K) of the 45 fish species according to each 398 modality of the explanatory factors (Geographical area, Sex, Sampling Year and 399 Quarter) on the relationship between body length and weight. Grey square indicate 400 that a factor appears to have a significant effect $(\mathrm{P}<0.05)$ on the $\mathrm{W}-\mathrm{L}$ relationship. 401 Only the individuals where the sex was determined were tested (F: female; M: male; 402 1: no sex available information). 


\begin{tabular}{|c|c|c|c|c|c|c|c|c|c|c|c|c|c|c|c|c|c|}
\hline \multirow[b]{2}{*}{ Order } & \multirow[b]{2}{*}{ Family } & \multirow[b]{2}{*}{ Species } & \multicolumn{5}{|c|}{ Areas } & \multicolumn{3}{|c|}{ Sex } & \multicolumn{3}{|c|}{ Year } & \multicolumn{4}{|c|}{ Quarter } \\
\hline & & & $8 A B$ & $\begin{array}{c}7 \mathrm{~g}, \mathrm{~h}, \\
\mathrm{j}\end{array}$ & $7 \mathrm{E}$ & $7 \mathrm{D}$ & 4 & $\mathrm{~F}$ & $M$ & -1 & 2013 & 2014 & 2015 & 1 & 2 & 3 & 4 \\
\hline \multicolumn{18}{|c|}{ Actinopterygii } \\
\hline \multirow{28}{*}{ 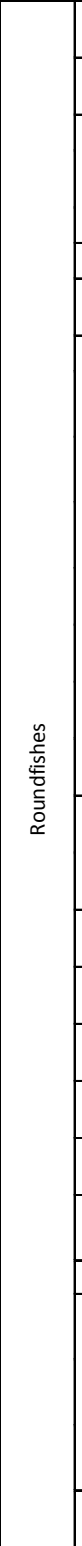 } & Ammodytidae & $\begin{array}{l}\text { Hyperoplus } \\
\text { immaculatus }\end{array}$ & & & 0,25 & 0,21 & & & & 0,27 & & 0,27 & & & & 0,25 & 0,27 \\
\hline & Carangidae & $\begin{array}{l}\text { Trachurus } \\
\text { trachurus }\end{array}$ & & & 0,94 & 0,92 & & & & 0,93 & & 0,93 & & & & 0,94 & 0,91 \\
\hline & \multirow{3}{*}{ Clupeidae } & Clupea harengus & & & & 0,68 & 0,61 & 0,63 & 0,62 & 0,64 & 0,64 & 0,63 & 0,61 & 0,62 & & 0,63 & 0,61 \\
\hline & & $\begin{array}{c}\text { Sardina } \\
\text { pilchardus }\end{array}$ & 0,77 & & & 0,88 & & 0,79 & 0,75 & 0,78 & 0,79 & 0,77 & 0,85 & & & 0,87 & 0,78 \\
\hline & & Sprattus sprattus & & & & 0,72 & 0,70 & 0,73 & 0,72 & 0,74 & 0,74 & 0,70 & 0,69 & 0,71 & & 0,82 & 0,87 \\
\hline & Congridae & Conger conger & 0,21 & 0,24 & 0,22 & 0,25 & & 0,22 & & 0,22 & 0,22 & 0,22 & 0,23 & & & 0,23 & 0,22 \\
\hline & Engraulidae & $\begin{array}{c}\text { Engraulis } \\
\text { encrasicolus }\end{array}$ & 0,61 & & 0,63 & 0,62 & & 0,62 & 0,62 & 0,63 & 0,61 & 0,63 & 0,65 & & & 0,64 & 0,62 \\
\hline & \multirow{8}{*}{ Gadidae } & Gadus morhua & & 1,05 & 1,10 & 1,03 & 1,02 & 1,04 & 1,03 & 1,01 & 1,04 & 1,02 & 1,04 & 1,03 & & 1,01 & 1,04 \\
\hline & & $\begin{array}{c}\text { Melanogrammus } \\
\text { aeglefinus } \\
\end{array}$ & 1,02 & 1,03 & 1,09 & 1,09 & 0,90 & 1,02 & 1,00 & 1,03 & 0,99 & 1,03 & 0,98 & 0,90 & & 1,09 & 1,03 \\
\hline & & $\begin{array}{c}\text { Merlangius } \\
\text { merlangus }\end{array}$ & 0,79 & 0,85 & 0,80 & 0,83 & 0,83 & 0,84 & 0,82 & 0,82 & 0,85 & 0,83 & 0,83 & 0,84 & & 0,80 & 0,83 \\
\hline & & $\begin{array}{c}\text { Micromesistius } \\
\text { poutassou }\end{array}$ & & & 0,69 & & & & & 0,69 & & 0,69 & & & & 0,69 & \\
\hline & & $\begin{array}{l}\text { Pollachius } \\
\text { pollachius }\end{array}$ & & & 0,93 & 0,97 & & 0,96 & 0,94 & 1,02 & & 0,97 & 0,94 & 0,97 & & 0,94 & 0,97 \\
\hline & & $\begin{array}{c}\text { Trisopterus } \\
\text { esmarkii }\end{array}$ & & & & & 0,71 & 0,75 & 0,69 & 0,70 & 0,75 & & 0,70 & 0,71 & & & \\
\hline & & $\begin{array}{c}\text { Trisopterus } \\
\text { luscus }\end{array}$ & & & 1,26 & 1,27 & & 1,29 & 1,27 & 1,31 & 1,31 & 1,31 & 1,23 & & & 1,27 & 1,30 \\
\hline & & $\begin{array}{l}\text { Trisopterus } \\
\text { minutus }\end{array}$ & & & 1,12 & 1,06 & & & & 1,08 & & 1,08 & & & & 1,09 & 1,05 \\
\hline & \multirow{2}{*}{ Lophiidae } & $\begin{array}{c}\text { Lophius } \\
\text { budegassa }\end{array}$ & 1,57 & 1,46 & & & & 1,55 & 1,49 & 1,59 & 1,52 & 1,61 & & & 1,55 & & 1,53 \\
\hline & & $\begin{array}{c}\text { Lophius } \\
\text { piscatorius }\end{array}$ & 1,28 & 1,45 & & & & 1,31 & 1,31 & 1,48 & 1,46 & 1,02 & & & 1,51 & & 1,31 \\
\hline & Merlucciidae & $\begin{array}{l}\text { Merluccius } \\
\text { merluccius }\end{array}$ & 0,71 & 0,71 & 0,77 & & & 0,71 & 0,69 & 0,78 & 0,73 & 0,70 & & & & 0,77 & 0,71 \\
\hline & Moronidae & $\begin{array}{c}\text { Dicentrarchus } \\
\text { labrax }\end{array}$ & 1,02 & 1,09 & 0,90 & 1,08 & 0,99 & 1,08 & 1,04 & 1,05 & 1,07 & 1,05 & 1,07 & 1,04 & & 1,06 & 1,06 \\
\hline & Mullidae & $\begin{array}{c}\text { Mullus } \\
\text { surmuletus }\end{array}$ & 1,28 & 1,30 & 1,32 & 1,09 & 1,08 & 1,31 & 1,28 & 1,25 & 1,29 & 1,31 & 1,26 & 1,11 & 1,22 & 1,31 & 1,33 \\
\hline & Phycidae & $\begin{array}{c}\text { Phycis } \\
\text { blennoides }\end{array}$ & 0,76 & 0,79 & & & & 0,80 & 0,73 & 0,73 & 0,75 & 0,79 & 0,77 & & & & 0,77 \\
\hline & Scombridae & $\begin{array}{c}\text { Scomber } \\
\text { scombrus }\end{array}$ & & & 0,89 & & & & & 0,89 & & 0,89 & & & & 0,89 & 0,87 \\
\hline & Sparidae & $\begin{array}{c}\text { Spondyliosoma } \\
\text { cantharus }\end{array}$ & & & 1,76 & 1,80 & & 1,75 & 1,76 & 1,78 & 1,80 & 1,76 & 1,79 & & & 1,77 & 1,80 \\
\hline & Trachinidae & Trachinus draco & & & & 0,66 & & 0,68 & 0,64 & 0,65 & 0,64 & 0,66 & 0,64 & & & 0,65 & 0,68 \\
\hline & \multirow{3}{*}{ Triglidae } & $\begin{array}{c}\text { Eutrigla } \\
\text { gurnardus }\end{array}$ & 0,83 & 0,84 & & 0,87 & 0,88 & 0,88 & 0,88 & 0,86 & 0,85 & 0,87 & 0,88 & 0,88 & & & 0,85 \\
\hline & & $\begin{array}{c}\text { Chelidonichthys } \\
\text { cuculus }\end{array}$ & 0,98 & 0,92 & 0,93 & 0,97 & & 0,97 & 0,92 & 0,97 & 0,97 & 0,94 & 0,98 & 0,95 & & 0,95 & 0,96 \\
\hline & & $\begin{array}{c}\text { Chelidonichthys } \\
\text { lucerna }\end{array}$ & 0,99 & 0,99 & & 1,00 & & 0,97 & 0,96 & 1,09 & 0,97 & 1,00 & 1,00 & 0,94 & & 1,00 & 1,00 \\
\hline & Zeidae & Zeus faber & 1,82 & 1,89 & 1,89 & 1,94 & & 1,78 & 1,72 & 1,83 & 1,72 & 1,63 & 1,75 & & & 1,51 & 1,94 \\
\hline \multirow{4}{*}{ 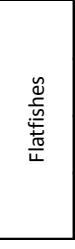 } & \multirow{3}{*}{ Scophthalmidae } & $\begin{array}{c}\text { Lepidorhombus } \\
\text { whiffiagonis } \\
\end{array}$ & 0,72 & 0,73 & 0,78 & & & 0,73 & 0,70 & 0,85 & 0,72 & 0,77 & & & 0,73 & 0,74 & 0,73 \\
\hline & & $\begin{array}{l}\text { Scophthalmus } \\
\text { maximus }\end{array}$ & 1,86 & 1,85 & 1,89 & 1,92 & 1,93 & 2,00 & 1,91 & 2,04 & 2,00 & 2,00 & 1,89 & 1,99 & 2,01 & 1,93 & 1,99 \\
\hline & & $\begin{array}{c}\text { Scophthalmus } \\
\text { rhombus }\end{array}$ & & 1,46 & & 1,43 & 1,41 & 1,43 & 1,36 & 1,41 & 1,33 & 1,41 & 1,34 & 1,41 & & 1,40 & 1,46 \\
\hline & Soleidae & Solea solea & 0,87 & 0,99 & 1,03 & 0,93 & 0,94 & 0,92 & 0,88 & 0,91 & 0,92 & 0,95 & 0,97 & 0,93 & 0,87 & 0,88 & 0,91 \\
\hline
\end{tabular}

404

405 


\begin{tabular}{|c|c|c|c|c|c|c|c|c|c|c|c|c|c|c|c|c|c|}
\hline \multirow{2}{*}{ Order } & \multirow{2}{*}{ Family } & \multirow{2}{*}{ Species } & \multicolumn{5}{|c|}{ Areas } & \multicolumn{3}{|c|}{ Sex } & \multicolumn{3}{|c|}{ Year } & \multicolumn{4}{|c|}{ Quarter } \\
\hline & & & $8 A B$ & $7 \mathrm{~g}, \mathrm{~h}, \mathrm{j}$ & $7 \mathrm{E}$ & $7 D$ & 4 & $\mathrm{~F}$ & M & -1 & 2013 & 2014 & 2015 & 1 & 2 & 3 & 4 \\
\hline \multicolumn{18}{|c|}{ Actinopterygii } \\
\hline \multirow{28}{*}{ 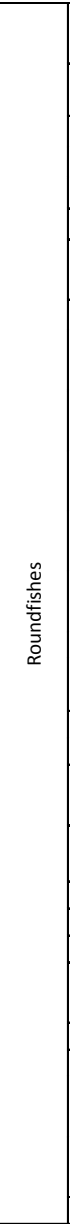 } & Ammodytidae & $\begin{array}{l}\text { Hyperoplus } \\
\text { immaculatus }\end{array}$ & & & 18 & 121 & & & & 139 & & 139 & & & & 18 & 121 \\
\hline & Carangidae & $\begin{array}{l}\text { Trachurus } \\
\text { trachurus } \\
\end{array}$ & & & 148 & 96 & & & & 244 & & 244 & & & & 162 & 82 \\
\hline & \multirow{3}{*}{ Clupeidae } & Clupea harengus & & & & 255 & 1087 & 666 & 662 & 14 & 490 & 360 & 492 & 1334 & & & \\
\hline & & Sardina pilchardus & 99 & & & 12 & & 47 & 51 & 13 & 47 & 66 & & & & & 104 \\
\hline & & Sprattus sprattus & & & & 154 & 473 & 335 & 265 & 27 & 257 & 176 & 194 & 626 & & & \\
\hline & Congridae & Conger conger & 27 & 30 & 20 & 17 & & 27 & & 67 & 32 & 62 & & & & 37 & 57 \\
\hline & Engraulidae & $\begin{array}{c}\text { Engraulis } \\
\text { encrasicolus }\end{array}$ & 170 & & 23 & 96 & & 147 & 108 & 34 & 94 & 195 & & & & 64 & 225 \\
\hline & \multirow{8}{*}{ Gadidae } & Gadus morhua & & 181 & 32 & 776 & 463 & 721 & 634 & 97 & 198 & 721 & 533 & 696 & & 181 & 575 \\
\hline & & $\begin{array}{c}\text { Melanogrammus } \\
\text { aeglefinus }\end{array}$ & 247 & 677 & 225 & 36 & 291 & 721 & 645 & 110 & 595 & 803 & 78 & 291 & & 227 & 958 \\
\hline & & $\begin{array}{l}\text { Merlangius } \\
\text { merlangus }\end{array}$ & 598 & 1298 & 409 & 2174 & 2341 & 3766 & 2685 & 369 & 1891 & 2460 & 2469 & 3222 & & 898 & 2700 \\
\hline & & $\begin{array}{c}\text { Micromesistius } \\
\text { poutassou }\end{array}$ & & & 52 & & & & & 52 & & 52 & & & & 52 & \\
\hline & & $\begin{array}{l}\text { Pollachius } \\
\text { pollachius }\end{array}$ & & & 17 & 33 & & 23 & 27 & & & 29 & 21 & 14 & & 20 & 16 \\
\hline & & $\begin{array}{c}\text { Trisopterus } \\
\text { esmarkii }\end{array}$ & & & & & 121 & 88 & 33 & & 54 & & 67 & 121 & & & \\
\hline & & Trisopterus luscus & & & 98 & 408 & & 195 & 243 & 68 & & 261 & 245 & & & 206 & 300 \\
\hline & & $\begin{array}{c}\begin{array}{c}\text { Trisopterus } \\
\text { minutus }\end{array} \\
\end{array}$ & & & 43 & 121 & & & & 164 & & 164 & & & & 115 & 49 \\
\hline & \multirow{2}{*}{ Lophiidae } & Lophius budegassa & 330 & 159 & & & & 205 & 175 & 109 & 388 & 101 & & & 151 & & 338 \\
\hline & & Lophius piscatorius & 240 & 135 & & & & 152 & 163 & 60 & 274 & 101 & & & 54 & & 321 \\
\hline & Merlucciidae & $\begin{array}{l}\text { Merluccius } \\
\text { merluccius }\end{array}$ & 958 & 1050 & 30 & & & 922 & 794 & 322 & 991 & 1047 & & & & 30 & 2008 \\
\hline & Moronidae & $\begin{array}{c}\text { Dicentrarchus } \\
\text { labrax }\end{array}$ & 105 & 23 & & 270 & 19 & 183 & 191 & 43 & 143 & 194 & 80 & 46 & & 57 & 314 \\
\hline & Mullidae & Mullus surmuletus & 136 & 108 & 45 & 540 & 75 & 452 & 298 & 154 & 165 & 326 & 413 & 143 & 71 & 226 & 464 \\
\hline & Phycidae & Phycis blennoides & 395 & 184 & & & & 388 & 91 & 100 & 186 & 237 & 156 & & & & 579 \\
\hline & Scombridae & Scomber scombrus & & & 43 & & & & & 43 & & 43 & & & & 43 & \\
\hline & Sparidae & $\begin{array}{l}\text { Spondyliosoma } \\
\text { cantharus }\end{array}$ & & & 82 & 127 & & 22 & 12 & 175 & & 209 & & & & 103 & 106 \\
\hline & Trachinidae & Trachinus draco & & & & 62 & & 14 & 32 & 16 & & 62 & & & & & 62 \\
\hline & \multirow{3}{*}{ Triglidae } & Eutrigla gurnardus & 13 & 10 & & 10 & 233 & 118 & 116 & 32 & 17 & 249 & & 233 & & & 33 \\
\hline & & $\begin{array}{l}\text { Chelidonichthys } \\
\text { cuculus }\end{array}$ & 242 & 183 & 174 & 744 & & 724 & 498 & 121 & 281 & 711 & 351 & 229 & & 352 & 762 \\
\hline & & $\begin{array}{l}\text { Chelidonichthys } \\
\text { lucerna }\end{array}$ & 19 & 49 & & 108 & & 73 & 37 & 66 & 108 & 49 & 19 & 88 & & & 88 \\
\hline & Zeidae & Zeus faber & 20 & 25 & 103 & 103 & & 44 & 10 & 197 & 48 & 175 & 28 & & & 123 & 128 \\
\hline \multirow{9}{*}{ 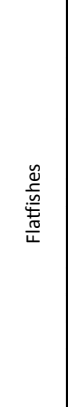 } & \multirow{3}{*}{ Scophthalmidae } & $\begin{array}{c}\text { Lepidorhombus } \\
\text { whiffiagonis }\end{array}$ & 683 & 266 & 28 & & & 579 & 333 & 65 & 605 & 372 & & & 200 & 28 & 749 \\
\hline & & $\begin{array}{l}\text { Scophthalmus } \\
\text { maximus }\end{array}$ & & 13 & & 47 & 14 & 30 & 21 & 23 & 13 & 28 & 33 & 38 & & & 36 \\
\hline & & $\begin{array}{l}\text { Scophthalmus } \\
\text { rhombus }\end{array}$ & & 10 & & 51 & & 28 & 12 & 21 & & 33 & 28 & & & & 61 \\
\hline & Soleidae & Solea solea & 482 & 35 & & 298 & 130 & 503 & 386 & 56 & 403 & 340 & 202 & 219 & 223 & 79 & 424 \\
\hline & \multirow{5}{*}{ Pleuronectidae } & $\begin{array}{c}\text { Glyptocephalus } \\
\text { cynoglossus }\end{array}$ & & 117 & & & & 60 & 57 & & & 55 & 62 & & & & 117 \\
\hline & & Limanda limanda & & & 23 & 231 & 731 & 659 & 289 & 37 & 454 & 531 & & 923 & & 36 & 26 \\
\hline & & Microstomus kitt & 52 & 199 & 83 & 169 & & 254 & 209 & 40 & 101 & 323 & 79 & & & 120 & 383 \\
\hline & & Platichthys flesus & & & & 39 & 59 & 29 & 57 & 12 & 98 & & & 98 & & & \\
\hline & & $\begin{array}{c}\text { Pleuronectes } \\
\text { platessa }\end{array}$ & & 243 & 32 & 2484 & 1925 & 2680 & 1874 & 130 & 1346 & 1325 & 2013 & 2887 & & 534 & 1232 \\
\hline \multicolumn{3}{|c|}{ Elasmobranchii } & & & & & & & & & & & & & & & \\
\hline & Arhynchobatidae & Raja brachyurops & & & & 45 & & 22 & 23 & & & 17 & 28 & & & & 45 \\
\hline
\end{tabular}

413 Supplementary Table 2. Parameters ' $a$ ' and ' $b$ ' with their Standard Error (S.E.) of the 414 relationship $\left(\mathrm{W}=\mathrm{aL}^{\mathrm{b}}\right)$ between weight $(\mathrm{W} ; \mathrm{g})$ and body length $(\mathrm{L} ; \mathrm{cm})$ for 45 species 415 caught from the Bay of Biscay to the North Sea during 2013, 2014 and 2015 years. 


\begin{tabular}{|c|c|c|c|c|c|c|}
\hline \multirow{2}{*}{ Order } & \multirow{2}{*}{ Family } & \multirow{2}{*}{ Species } & \multicolumn{2}{|c|}{$a$} & \multicolumn{2}{|c|}{$b$} \\
\hline & & & mean & SE & mean & SE \\
\hline \multicolumn{7}{|c|}{ Actinopterygii } \\
\hline \multirow{28}{*}{ 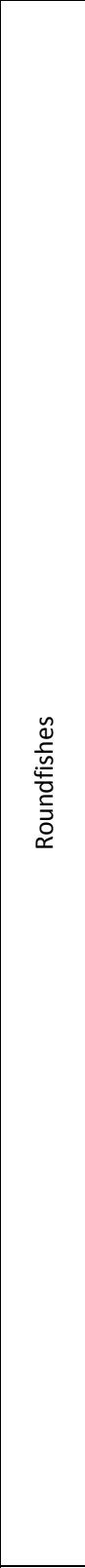 } & Ammodytidae & $\begin{array}{l}\text { Hyperoplus } \\
\text { immaculatus }\end{array}$ & 0,010 & 0,008 & 2,671 & 0,012 \\
\hline & Carangidae & Trachurus trachurus & 0,016 & 0,003 & 2,830 & 0,054 \\
\hline & \multirow{3}{*}{ Clupeidae } & Clupea harengus & 0,006 & 0,000 & 3,037 & 0,026 \\
\hline & & Sardina pilchardus & 0,003 & 0,001 & 3,322 & 0,093 \\
\hline & & Sprattus sprattus & 0,006 & 0,002 & 3,032 & 0,098 \\
\hline & Congridae & Conger conger & 0,000 & 0,000 & 3,472 & 0,008 \\
\hline & Engraulidae & Engraulis encrasicolus & 0,001 & 0,000 & 3,353 & 0,050 \\
\hline & \multirow{8}{*}{ Gadidae } & Gadus morhua & 0,005 & 0,000 & 3,185 & 0,023 \\
\hline & & $\begin{array}{c}\text { Melanogrammus } \\
\text { aeglefinus }\end{array}$ & 0,008 & 0,001 & 3,073 & 0,017 \\
\hline & & Merlangius merlangus & 0,006 & 0,000 & 3,095 & 0,007 \\
\hline & & $\begin{array}{c}\text { Micromesistius } \\
\text { poutassou }\end{array}$ & 0,007 & 0,001 & 2,988 & 0,043 \\
\hline & & Pollachius pollachius & 0,032 & 0,014 & 2,709 & 0,108 \\
\hline & & Trisopterus esmarkii & 0,004 & 0,001 & 3,232 & 0,073 \\
\hline & & Trisopterus luscus & 0,009 & 0,001 & 3,096 & 0,034 \\
\hline & & Trisopterus minutus & 0,018 & 0,003 & 2,810 & 0,053 \\
\hline & \multirow{2}{*}{ Lophiidae } & Lophius budegassa & 0,046 & 0,008 & 2,704 & 0,042 \\
\hline & & Lophius piscatorius & 0,011 & 0,003 & 3,039 & 0,068 \\
\hline & Merlucciidae & Merluccius merluccius & 0,008 & 0,001 & 2,964 & 0,015 \\
\hline & Moronidae & Dicentrarchus labrax & 0,034 & 0,006 & 2,701 & 0,045 \\
\hline & Mullidae & Mullus surmuletus & 0,009 & 0,001 & 3,109 & 0,018 \\
\hline & Phycidae & Phycis blennoides & 0,010 & 0,001 & 2,946 & 0,028 \\
\hline & Scombridae & Scomber scombrus & 0,002 & 0,000 & 3,439 & 0,066 \\
\hline & Sparidae & $\begin{array}{l}\text { Spondyliosoma } \\
\text { cantharus }\end{array}$ & 0,010 & 0,002 & 3,152 & 0,043 \\
\hline & Trachinidae & Trachinus draco & 0,013 & 0,006 & 2,814 & 0,116 \\
\hline & \multirow{3}{*}{ Triglidae } & Eutrigla gurnardus & 0,009 & 0,002 & 2,994 & 0,058 \\
\hline & & $\begin{array}{l}\text { Chelidonichthys } \\
\text { cuculus }\end{array}$ & 0,008 & 0,000 & 3,059 & 0,018 \\
\hline & & $\begin{array}{l}\text { Chelidonichthys } \\
\text { lucerna }\end{array}$ & 0,006 & 0,001 & 3,168 & 0,027 \\
\hline & Zeidae & Zeus faber & 0,035 & 0,004 & 2,793 & 0,046 \\
\hline \multirow{9}{*}{ 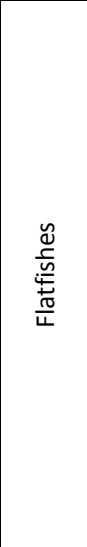 } & \multirow{3}{*}{ Scophthalmidae } & $\begin{array}{l}\text { Lepidorhombus } \\
\text { whiffiagonis }\end{array}$ & 0,003 & 0,000 & 3,223 & 0,023 \\
\hline & & $\begin{array}{l}\text { Scophthalmus } \\
\text { maximus }\end{array}$ & 0,066 & 0,048 & 2,688 & 0,185 \\
\hline & & $\begin{array}{l}\text { Scophthalmus } \\
\text { rhombus }\end{array}$ & 0,009 & 0,002 & 3,124 & 0,073 \\
\hline & Soleidae & Solea solea & 0,004 & 0,000 & 3,251 & 0,026 \\
\hline & \multirow{5}{*}{ Pleuronectidae } & $\begin{array}{c}\text { Glyptocephalus } \\
\text { cynoglossus }\end{array}$ & 0,002 & 0,001 & 3,299 & 0,064 \\
\hline & & Limanda limanda & 0,007 & 0,001 & 3,136 & 0,021 \\
\hline & & Microstomus kitt & 0,012 & 0,001 & 2,995 & 0,033 \\
\hline & & Platichthys flesus & 0,002 & 0,001 & 3,433 & 0,132 \\
\hline & & Pleuronectes platessa & 0,005 & 0,000 & 3,195 & 0,012 \\
\hline \multicolumn{7}{|c|}{ Elasmobranchii } \\
\hline & Arhynchobatidae & Raja brachyurops & 0,002 & 0,002 & 3,303 & 0,231 \\
\hline
\end{tabular}




\begin{tabular}{|c|c|c|c|c|c|}
\multirow{4}{*}{ Rajidae } & Raja clavata & 0,003 & 0,001 & 3,174 & 0,055 \\
\cline { 2 - 6 } & Raja montagui & 0,002 & 0,001 & 3,263 & 0,154 \\
\cline { 2 - 6 } & Raja undulata & 0,002 & 0,001 & 3,321 & 0,127 \\
\hline \multirow{4}{*}{ Scyliorhinidae } & Scyliorhinus canicula & 0,002 & 0,001 & 3,151 & 0,100 \\
\cline { 2 - 6 } & Scyliorhinus stellaris & 0,002 & 0,001 & 3,167 & 0,092 \\
\hline \multirow{2}{*}{ Trakidae } & Galeorhinus galeus & 0,005 & 0,000 & 3,185 & 0,023 \\
\cline { 2 - 6 } & Mustelus asterias & 0,002 & 0,001 & 3,159 & 0,043 \\
\hline
\end{tabular}

416

417

418

419

420

421

422

423

424

425

426

427

428

429

430

431

432

433 
Supplementary Table 3. Reproduction period of the 45 fish species with sampled geographical area and the reference in FishBase. Grey Squares with one star are the reproduction months by each species.

\begin{tabular}{|c|c|c|c|c|c|c|c|c|c|c|c|c|c|c|c|}
\hline Family & Species & Jan & Feb & Mar & Apr & May & Jun & Jul & Aug & Sep & Oct & Nov & Dec & Area & Reference \\
\hline \multicolumn{16}{|l|}{ tinopterygii } \\
\hline 4mmodytidae & Hyperoplus immaculatus & $*$ & $*$ & & & & & & & & & & & $\begin{array}{l}\text { Eastern } \\
\text { Atlantic }\end{array}$ & 1 \\
\hline Carangidae & Trachurus trachurus & & & & $*$ & $*$ & $*$ & $*$ & & & & & & $\begin{array}{l}\text { Celtic } \\
\text { Sea }\end{array}$ & 2 \\
\hline \multirow{3}{*}{ Clupeidae } & Clupea harengus & $*$ & $*$ & * & & & & & & & * & * & * & $\begin{array}{c}\text { Celtic } \\
\text { Sea }\end{array}$ & 3 \\
\hline & Sardina pilchardus & & & & $*$ & & & & & & & & & $\begin{array}{l}\text { English } \\
\text { Channel } \\
\end{array}$ & 4 \\
\hline & Sprattus sprattus & & $*$ & $*$ & $*$ & $*$ & $*$ & $*$ & & & & & & $\begin{array}{c}\text { Scotland } \\
\text { coasts }\end{array}$ & 5 \\
\hline Congridae & Conger conger & & & & & & $*$ & $*$ & $*$ & & & & & Portugal & 6 \\
\hline Engraulidae & Engraulis encrasicolus & & & & $*$ & $*$ & $*$ & $*$ & $*$ & & & & & $\begin{array}{l}\text { Bay of } \\
\text { Biscay }\end{array}$ & 7 \\
\hline \multirow{8}{*}{ Gadidae } & Gadus morhua & $*$ & $*$ & $*$ & $*$ & * & & & & & & & & Irish Sea & 8 \\
\hline & Melanogrammus aeglefinus & & $*$ & $*$ & $*$ & & & & & & & & & $\begin{array}{l}\text { Celtic } \\
\text { Sea }\end{array}$ & 9 \\
\hline & Merlangius merlangus & $*$ & $*$ & $*$ & $*$ & $*$ & $*$ & $*$ & $*$ & $*$ & & & & \begin{tabular}{|c|} 
Between \\
British \\
Isles and \\
Bay of \\
Biscay \\
\end{tabular} & 10 \\
\hline & Micromesistius poutassou & & $*$ & $*$ & & & & & & & & & & $\begin{array}{c}\text { British } \\
\text { isles }\end{array}$ & 11 \\
\hline & Pollachius pollachius & $*$ & $*$ & $*$ & $*$ & $*$ & & & & & & & & $\begin{array}{c}\text { Northeast } \\
\text { Atlantic }\end{array}$ & 12 \\
\hline & Trisopterus esmarkii & $*$ & $*$ & $*$ & & & & & & & & & & $\begin{array}{c}\text { Scotland } \\
\text { coasts }\end{array}$ & 11 \\
\hline & Trisopterus luscus & $*$ & $*$ & * & $*$ & & & & & & & & $*$ & Atlantic & 10 \\
\hline & Trisopterus minutus & & $*$ & $*$ & & & & & & & & & & $\begin{array}{l}\text { English } \\
\text { Channel }\end{array}$ & 10 \\
\hline \multirow[t]{2}{*}{ Lophiidae } & Lophius budegassa & $*$ & $*$ & & & & & & & & & $*$ & $*$ & $\begin{array}{c}\text { Atlantic } \\
\text { Iberian } \\
\text { Coast } \\
\end{array}$ & 13 \\
\hline & Lophius piscatorius & & & $*$ & $*$ & * & $*$ & & & & & & & $\begin{array}{c}\text { British } \\
\text { isles }\end{array}$ & 11 \\
\hline Merlucciidae & Merluccius merluccius & $*$ & $*$ & $*$ & $*$ & $*$ & & & & & & & & $\begin{array}{c}\text { North } \\
\text { Sea }\end{array}$ & 11 \\
\hline Moronidae & Dicentrarchus labrax & & $*$ & $*$ & $*$ & $*$ & $*$ & & & & & & & $\begin{array}{c}\text { British } \\
\text { isles } \\
\end{array}$ & 14 \\
\hline Mullidae & Mullus surmuletus & & & & & $*$ & $*$ & $*$ & & & & & & $\begin{array}{c}\text { North } \\
\text { Sea }\end{array}$ & 15 \\
\hline Phycidae & Phycis blennoides & & & $*$ & $*$ & $*$ & $*$ & $*$ & & & & & & $\begin{array}{c}\text { North } \\
\text { Atlantic }\end{array}$ & 10 \\
\hline Scombridae & Scomber scombrus & & & & & $*$ & $*$ & & & & & & & $\begin{array}{l}\text { British } \\
\text { isles }\end{array}$ & 11 \\
\hline Sparidae & Spondyliosoma cantharus & & & & $*$ & $*$ & & & & & & & & $\begin{array}{c}\text { British } \\
\text { isles }\end{array}$ & 19 \\
\hline Trachinidae & Trachinus draco & - & - & - & - & - & - & - & - & - & - & - & - & & \\
\hline \multirow[t]{3}{*}{ Triglidae } & Eutrigla gurnardus & & & & $*$ & $*$ & $*$ & $*$ & $*$ & & & & & $\begin{array}{l}\text { North } \\
\text { Sea }\end{array}$ & 11 \\
\hline & Chelidonichthys cuculus & $*$ & $*$ & $*$ & $*$ & $*$ & $*$ & $*$ & & & & & & $\begin{array}{c}\text { Northeast } \\
\text { Atlantic }\end{array}$ & 21 \\
\hline & Chelidonichthys lucerna & $*$ & $*$ & $*$ & $*$ & & & & & & $*$ & $*$ & $*$ & Tunisia & 22 \\
\hline Zeidae & Zeus faber & $*$ & * & * & $*$ & & & & & & & & & $\begin{array}{c}\text { British } \\
\text { isles }\end{array}$ & 11 \\
\hline cophthalmidae & Lepidorhombus whiffiagonis & & & $*$ & $*$ & $*$ & $*$ & & & & & & & \begin{tabular}{|c|} 
Northeast \\
Atlantic
\end{tabular} & 11 \\
\hline
\end{tabular}

4381 Reay P.J. (1986) Ammodytidae. p. 945-950. In P.J.P. Whitehead, M.-L. Bauchot, J.-C. 439 Hureau, J. Nielsen and E. Tortonese (eds.) Fishes of the north-eastern Atlantic and the 440 Mediterranean. UNESCO, Paris. Vol. 2.

4412 Eltink A. Vingerhoed B.(1989) The total fecundity of Western horse mackerel 442 (Trachurus trachurus L.). ICES:C.M. H(44):11p. 

444 subsequent growth and age at first spawning in Atlantic herring (Clupea harengus L.). ICES J. 445 Mar. Sci. 60:1103-1113.

4464 Whitehead P.J.P. (1985) FAO Species Catalogue. Vol. 7. Clupeoid fishes of the world 447 (suborder Clupeioidei). An annotated and illustrated catalogue of the herrings, sardines, 448 pilchards, sprats, shads, anchovies and wolf-herrings. FAO Fish. Synop. 125(7/1):1-303. 449 Rome: FAO.

4505 De Silva S.S. (1973) Aspects of the reproductive biology of the sprat, Sprattus 451 sprattus in inshore waters of the west coast of Scotland. J. Fish Biol. 5:689-705.

$4526 \quad$ Bauchot M.-L. Saldanha L. (1986) Congridae (including Heterocongridae). p. 567-574. 453 In P.J.P. Whitehead, M.-L. Bauchot, J.-C. Hureau, J. Nielsen and E. Tortonese (eds.) Fishes of 454 the north-eastern Atlantic and the Mediterranean. volume 2. UNESCO, Paris.

4557 Uriarte A. Prouzet P. Villamor B. (1996) Bay of Biscay and Ibero Atlantic anchovy 456 populations and their fisheries. Sci. Mar. 60 (Supl. 2):237-255.

4578 Nash R.D.M. Pilling G.M. Kell L.T. Schön P.-J. Kjesbu O.S. (2010) Investment in 458 maturity-at-age and -length in northeast Atlantic cod stocks. Fish. Res. 104(1-3):89-99.

4599 ICES (2012) Report of the Working Group for the Celtic Seas Ecoregion (WGCSE), 9-18 460 May 2012, Copenhagen, Denmark. ICES CM 2012/ACOM:12. 1743 p.

46110 Cohen D.M. Inada T. Iwamoto T. Scialabba N. (1990) FAO species catalogue. Vol. 10. 462 Gadiform fishes of the world (Order Gadiformes). An annotated and illustrated catalogue of 463 cods, hakes, grenadiers and other gadiform fishes known to date. FAO Fish. Synop. 125(10). 464 Rome: FAO. 442 p.

46511 Muus B.J. Nielsen J.G. (1999) Sea fish. Scandinavian Fishing Year Book, Hedehusene, 466 Denmark. $340 \mathrm{p}$.

46712 Svetovidov A.N. (1986) Gadidae. p. 680-710. In P.J.P. Whitehead, M.-L. Bauchot, J.-C. 468 Hureau, J. Nielsen and E. Tortonese (eds.) Fishes of the north-eastern Atlantic and the 469 Mediterranean. UNESCO, Paris. vol. 2.

47013 Landa J. Pereda P. Duarte R. Azevedo M. (2001) Growth of anglerfish (Lophius 471 piscatorius and L. budegassa) in Atlantic Iberian waters. Fish. Res. 51(2-3):363-376.

47214 Tortonese E. (1986) Moronidae. p. 793-796. In P.J.P. Whitehead, M.-L. Bauchot, J.-C. 473 Hureau, J. Nielsen and E. Tortonese (eds.) Fishes of the north-eastern Atlantic and the 474 Mediterranean. UNESCO, Paris. vol. 2.

$47515 \quad$ N'Da K. Déniel C. (1993). Sexual cycle and seasonal changes in the ovary of the red 476 mullet, Mullus surmuletus, from the southern coast of Brittany. J. Fish Biol. 43(2):229-244.

47716 Billard R. (1997) Les poissons d'eau douce des rivières de France. Identification, 478 inventaire et répartition des 83 espèces. Lausanne, Delachaux \& Niestlé, 192p. 
47917 ICES (2012) Report of the Working Group on the Assessment of Demersal Stocks in 480 the North Sea and Skagerrak (WGNSSK), 27 April - 03 May 2012, ICES Headquarters, 481 Copenhagen. ICES CM 2012/ACON:13. 1346 p.

48218 Nielsen J.G. (1986) Scophthalmidae. p. 1287-1293. In P.J.P. Whitehead, M.-L. 483 Bauchot, J.-C. Hureau, J. Nielsen and E. Tortonese (eds.) Fishes of the North-eastern Atlantic 484 and the Mediterranean. UNESCO, Paris. Vol. 3.

48519 Druzhinin A.D. (1976) Sparid fishes of the world oceans. Moscow, Pishchevaya 486 Promyshlennost, $195 \mathrm{p}$.

48720 Quéro J.-C. Desoutter M. Lagardère F. (1986) Soleidae. p. 1308-1324. In P.J.P. 488 Whitehead, M.-L. Bauchot, J.-C. Hureau, J. Nielsen and E. Tortonese (eds.) Fishes of the 489 North-eastern Atlantic and the Mediterranean. UNESCO, Paris. Vol. 3.

49021 Fischer W. Bauchot M.-L. Schneider M. (eds.) (1987) Fiches FAO d'identification des 491 espèces pour les besoins de la pêche. (Révision 1). Méditerranée et mer Noire. Zone de 492 Pêche 37. FAO, Rome. 1529 p.

49322 Boudaya L. Neifar L. Rizzo P. Badalucco C. Bouain A. Fiorentino F. (2008) Growth and 494 reproduction of Chelidonichthys lucerna (Linnaeus) (Pisces: Triglidae) in the Gulf of Gabès, 495 Tunisia. J. Appl. Ichthyol. 24(5):581-588.

49623 Holden J.M. (1975) The fecundity of Raja clavata in British waters. J. Cons. Int. 497 Explor. Mer. 36(2):110-118.

49824 Stehmann M. Bürkel D.L. (1984) Rajidae. p. 163-196. In P.J.P. Whitehead, M.-L. 499 Bauchot, J.-C. Hureau, J. Nielsen and E. Tortonese (eds.) Fishes of the north-eastern Atlantic 500 and Mediterranean. UNESCO, Paris. vol. 1.

50125 Compagno L.J.V. (1984) FAO Species Catalogue. Vol. 4. Sharks of the world. An 502 annotated and illustrated catalogue of shark species known to date. Part 2 503 Carcharhiniformes. FAO Fish. Synop. 125(4/2):251-655. Rome: FAO.

50426 Last P.R. Stevens J.D. (1994) Sharks and rays of Australia. CSIRO, Australia. 513 p.

50527 McCully Phillips S.R. Ellis J.R. (2015) Reproductive characteristics and life-history 506 relationships of starry smooth-hound Mustelus asterias in British waters. J Fish Biol, 87: 507 1411-1433.

508 